\title{
Pesantren Raudhatul Jannah: Strategi Peningkatan Kemudahan Berusaha Dimasa Pandemi dengan Program- Program Pemberdayaan Keumatan
}

Sidiq Pramana Widagda

Sekolah Tinggi Pariwisata AMPTA, Yogyakarta, Indonesia, email: sidiq_pw@yahoo.com

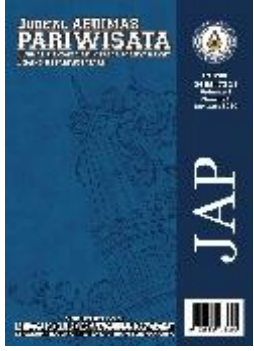

\begin{tabular}{|c|c|}
\hline \multicolumn{2}{|c|}{ Informasi artikel } \\
\hline $\begin{array}{l}\text { Sejarah } \\
\text { artikel }\end{array}$ & \\
\hline Diterima & : 1 Desember 2020 \\
\hline Revisi & : 21 Desember 2020 \\
\hline Dipublikasikan & : 1 Januari 2021 \\
\hline
\end{tabular}

Kata kunci:

Wisata halal

Pemberdayaan

PPPA Raudhatul Jannah

\begin{abstract}
ABSTRAK
Pesantren Tahfizh Raudhatul Jannah adalah gambaran lembaga yang menggabungkan semangat pendidikan dan wirausaha dikalangan santrinya. Semangat wirausaha tersebut juga dengan memberdayakan masyarakat sekitar dengan memenfaatkan lahan-lahan yang ada. Adapun tujuan dari tulisan ini adalah memaparkan tujuan dan keberadaan Pesantren Tahfizh Raudhatul Jannah dan bagaimana usaha Pesantren Tahfizh Raudhatul Jannah dalam memanfaatkan potensi wisata halal yang ada dan menciptakan berbagai usaha dalam memberdayakan masyarakat sekitar.Adanya peningkatan wisatawan muslim dari tahun ke tahun merupakan peluang dan tantangan bagi sektor pariwisata untuk mengembangkan wisata halal. Pengembangan wisata halal yang dilakukan oleh PPPA Raudhatul Jannah dengan membuat program paket wisata dengan mengikuti program Pondok pesantren bisa menghafal al-qur'an dan mengadakan pelatihan pengembangan wisata halal dan menjadikan pondok pesantren sebagai jantung perekonomian dengan melakukan berbagai kegiatan usaha, mulai dari beternak lele, kambing, penanaman jeruk dan pisang.
\end{abstract}

Keywords:

Halal tourism

Empowerment

PPPA Raudhatul Jannah

\begin{abstract}
Pesantren Raudhatul Jannah: Strategies for Increasing Ease of Doing Business in the Pandemic Era with Public Empowerment Programs. The Tahfizh Raudhatul Jannah Islamic Boarding School is a picture of an institution that combines the spirit of education and entrepreneurship among its students. This entrepreneurial spirit also empowers the surrounding community by utilizing existing lands. This paper aims to describe the purpose and existence of the Tahfizh Raudhatul Jannah Islamic Boarding School and how the efforts of the Tahfizh Raudhatul Jannah Islamic Boarding School to exploit the existing potential of halal tourism and create various efforts to empower the surrounding community. The increase in Muslim tourists from year to year is an opportunity and a challenge for the tourism sector to develop halal tourism. Halal tourism development is carried out by creating a tour package program. Tourists must take part in activities at the pesantren so that they can memorize the Koran. This program makes Islamic boarding schools the centre of the economy by carrying out various business activities, ranging from raising catfish, goats, planting oranges and bananas.
\end{abstract}

\section{Pendahuluan}

Sektor pariwisata merupakan salah satu sektor yang mampu meningkatkan lapangan kerja dan pertumbuhan ekonomi. Saat ini, wisata halal (halal tourism) mulai banyak diminati. Hal tersebut seiring dengan peningkatan wisatawan muslim dari tahun ke tahun. Pengembangan wisata halal mulai banyak dilakukan oleh berbagai negara, baik negara dengan mayoritas muslim maupun nonmuslim. (Eka Dewi S, Hayyun D F, 2018). 
Hal ini tentu tidak terjadi begitu saja, butuh kesadaran yang baik untuk semua pihak dalam menyadari potensi-potensi lokal yang dapat dikembangkan secara baik dan profesional. Baik kesadaran akan potensi alam, potensi kuliner yang bisa dikembangkan, potensi program-program yang dapat mendukung segala konsep wisata halal yang akan dikembangkan.

Praktek di lapangan, pengetahuan dan kesadaran akan produk halal menjadikan pertumbuhan industri halal semakin meningkat (Rahman et al. 2011; Hamdan et al. 2013). Meningkatnya industri halal tersebut, memunculkan wisata halal (halal tourism) sebagai fenomena baru (Samori et al. 2016). Hal ini juga didukung oleh berbagai literatur yang menjelaskan bahwa wisatawan muslim peduli terhadap konsumsi produk dan layanan sesuai syariah ketika berkunjung ketempat wisata (Battour et al. 2010; Battour et al. 2012; Jafari dan Scott, 2014).

Banyaknya konsep-konsep wisata halal yang telah dikembangkan, lebih banyak lahir dari pengusaha-pengusaha yang notabenenya adalah perorang atau individu-individu, atau juga lahir dari program-program pemerintah yang bekerja sama dengan pihakswasta. Namun kita jarang sekali melihat konsep wisata halal ini dilakukan oleh lembaga pendidikan atau sekolah. Kondisi itulah yang pada akhirnya dimanfaatkan oleh pendiri dan pengurus Pesantren Raudhatul Jannah yang berlokasi di utara Pantai Kwaru, Bodowaluh, Karang RT 04, Poncosari, Srandakan, Bantul.

Kesadaran akan potensi alam dan sumdar daya manusia yang ada, maka Pesantren Raudhatul Jannah yang digawangi oleh para pengurus Pesantren memadukan dakwah Islam dengan konsep wisata halal dengan mengembangkan potensi keumatan yang ada. Konsep ini memadukan pendidikan, wisata dan entrepreneurship. Konsep yang ditawarkan adalah pendidikan Islam di bidang Tahfizhul Qur'an dengan mengarahkan program-program pesantren untuk mewujudkan pembinaan karakter berakhlak mulia, pribadi mandiri, dan pribadi yang bermanfaat. Pesantren Tahfizh Raudhatul Jannah juga memberikan skill khusus disamping menghafal Al Qur'an para santri dibekali ilmu entrepreneur dengan tujuan agar para santri mampu menopang ekonomi dirinya kelak, mulai dari memberdayakan lingkungan wisata yang ada, kemudian penanaman beberapa tanaman produktif dan beternak kambing. Konsep wisata halal yang ditawarkan oleh Pesantren Tahfizh Raudhatul Jannah memiliki potensi wisata yang sangat besar, hal ini seiring dengan meningkatnya peminat wisata halal yang terasa beberapa tahun belakangan, (Battour dan Ismail, 2016).

Berikut adalah gambaran dari konsep yang telah dilakukan dan akan dikembangkan oleh Pesantren Tahfizh Raudhatul Jannah:

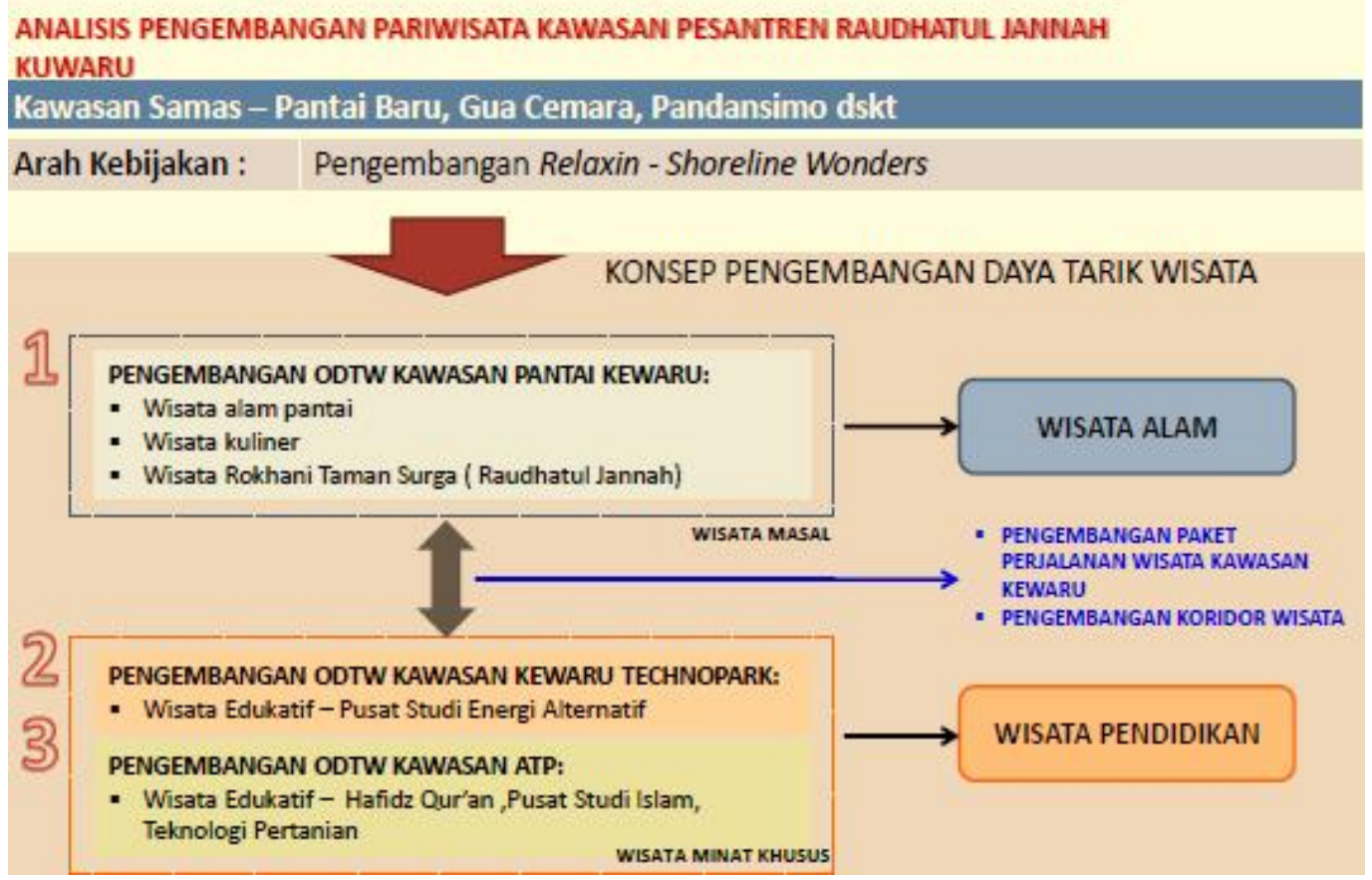

Gambar 1. Penyusunan Rencana Induk Pengembangan PPPA Raudhatul Jannah 
Peningkatan tersebut seiring dengan meningkatnya wisatawan muslim dari tahun ke tahun (ElGohary, 2016 dan Handerson, 2016). Wisatawan muslim diperkirakan akan meningkat sebesar 30 persen pada tahun 2020 dan juga meningkatkan nilai pengeluaran hingga 200 miliar USD (Master Card dan Crescent Rating, 2016). Untuk mengeksplorasi potensi besar pariwisata halal tersebut, banyak negara (baik negara dengan mayoritas muslim maupun non-muslim) mulai menyediakan produk, fasilitas, dan infrastruktur pariwisata untuk memenuhi kebutuhan wisatawan muslim. Namun, masih banyak para pelaku bisnis dan pihak yang terlibat di sektor pariwisata terkendala dalam pemahaman (baik produk, fasilitas maupun infrastruktur) dari wisata halal tersebut (Mohsin et al. 2016; Han et al. 2018).

Berdasarkan paparan di atas, sebagai lembaga pendidikan yang memiliki konsentrasi dalam melahirkan para penghafalan al-Qur'an, Pesantren Tahfizh Raudhatul Jannah juga bergerak dalam kegiatan keumatan yang memiliki sebuah visi kedepan yang bisa memberdayakan para santrisantrinya serta bisa memaksimalkan potensi alam sekitar, sehingga memiliki nilai jual dan nilai ekonomi yang tinggi. Adapun tujuan dari tulisan ini adalah memaparkan tujuan dan keberadaan Pesantren Tahfizh Raudhatul Jannah dan bagaimana usaha Pesantren Tahfizh Raudhatul Jannah dalam memanfaatkan potensi wisata yang ada dan menciptakan berbagai usaha dalam memberdayakan masyarakat sekitar.

\section{Metode}

Penelitian ini merupakan penelitian lapangan yang bersifat deskriptif dengan pendekatan kualitatif, dimana peneliti mengumpulkan berbagai data yang bisa memberikan gambaran atau menyajikan permasalahan dan pemecahan masalah yang ada. Data dalam penelitian ini dikumpulkan melalui observasi, dokumentasi dan wawancara informal dari beberapa pihak untuk memperkuat data yang diinginkan.Pengolahan data dilakukan berdasarkan pada setiap perolehan data dari catatan lapangan, direduksi, dideskripsikan, dianalisis, kemudian ditafsirkan.Prosedur analisis data terhadap masalah lebih difokuskan pada upaya menggali fakta sebagaimana adanya natural setting, dengan teknik analisis pendalaman kajian verstegen.Prosedur di atas sebagai upaya uji keabsahan data dalam penelitian kualitatif, langkah tersebut dinamakan dengan teknik triangulasi. Teknik ini merupakan teknik pemeriksaan keabsahan data yang memanfaatkan sesuatu yang lain di luar data sebagai pembanding terhadap data tersebut (Pawito, 2007).

\section{Hasil dan Pembahasan}

\section{Profil Pesantren Rodhatul Jannah}

Pondok Pesantren Penghafal Alquran (PPPA) Raudhatul Jannah terletak di utara Pantai Kwaru, Bodowaluh, Karang RT 04, Poncosari, Srandakan, Bantul. Sejak dirintis tahun 2014, Pondok Pesantren Penghafal Al Qur'an (PPPA) Raudhatul Jannah hingga kini terus menjaga komitmennya mengajarkan membaca Al Qur'an bagi masyarakat. Selain itu, pengasuh PPPA tersebut juga mendampingi santri sepuh agar bisa membaca Al Qur'an. Jumlah santri 65orang, yang terdiri dari santri anak usia dibawah 13 tahun juga santri mahasiswa yang pernah mondok di Gontor kuliah sambil menghafal Al Qur'an di Raudhatul Jannah.

Prestasi menghafal alqur'an ada yang umurnya baru 6,5th sudah hafal 6juz, Isma Muhamad Ihsan dan juara II se DIY. Selain kegitan utama menghafal al-Qur'an, pihak pondok juga melatih jiwa kesatria santri dengan latihan Bela diri Tae Kwon Do, untuk Dewasa olah raga seni Asli budaya Jogja Merpati Putih(Mersudi Patitising Tindak Pusakane Titising Hening). Berikut adalah program pendidikan di Pesantren dan juga pendidikan Formal di luar Pesantren:

1. Tahfidzul Qur'an

Pondok Pesantren Penghafal Al Qur'an (PPPA) Raudhatul Jannah memiliki program utama untuk terus menjaga komitmennya mengajarkan membaca Al-qur' an bagi masyarakat.

2. Tahsin Dan Tartil 
PPPA mengajarkan untuk membaguskan bacaan Al Qur'an atau dengan kata lain membaca $\mathrm{Al}$ Qur'an dengan sebaik-baiknya dengan menggunakan kaidah-kaidah ilmu tajwid.

3. Tafsir Dan Terjemah Dasar

Belajar terjemahan dasar Al Quran dan belajar ilmu tafsir untuk mempelajari isi kandungan Al Quran

4. Pendidikan Sekolah Formal

Mengikutkan Santri belajar disekolah formal di sekolah terdekat dengan Pesantren.

5. Program Umum

Program baca Al -Qur' an untuk umum, orang "Dewasa" dari tidak bisa menjadi bisa baca, 5 jam saja.

6. Unit Usaha PPPA Raudatul Jannah

PPPA Raudatul Jannah disamping focus dalam hafalan Al Qur'an. Santri juga dibekali jiwa entrepreneur dengan berbagai unit usaha dengan menjual madu klanceng dan madu NTT.

Selain kegiatan seperti yang telah dijelaskan di atas, santri juga dibekali jiwa entrepreneur dengan berbagai unit usaha, seperti membuat panah beserta busurnya, Packaging Madu, bekerja sama dengan tim dakwah menerima Madu Murni dari hutan NTT dikemas kemudian di Pasarkan di Yogyakarta dan sekitarnya, sejumlah kegiatan juga diadakan di PPPA Raudhatul Jannah diantaranya, Bercocok tanam; Sayuran, rempah-rempah juga buah-buahan, Olah RagaTae Kwon Do, hingga kegiatan memanah.

PPPA Raudhatul Jannah memberikan kesempatan kapada santri untuk bercocok tanam untuk menumbuhkan jiwa santri berwirausaha, lewat ternak ayam, kambing juga sapi. Sejak PPPA didirikan, ponpes tersebut punya visi membentuk generasi Qurani sejak usia dini. Selain itu, dalam membentuk generasi mahir membaca Al Qu'ran, harus dilakukan pembinaan sejak dini.Pondok Pesantren mempersiapkan kader penghafal Al Qur'an supaya bisa menjadi imam dan meneruskan estafet perjuangan Rasulullah. Sementara untuk program pesantren diantaranya, Tahfidzul Qur'an, Tahsin dan Tartil, Tafsir dan terjemah dasar hingga kewirausahaan.

Agrobisnis, bercocok tanan pohon Pepaya Kelapa Kopyor, Jeruk, dan berbagai jenis tanaman buah, Ternak Kambing, di bimbing langsung dari Fakultas Kedokteran Hewan UGM. Dalam Pengembangangan Pariwisata pak Tazbir Abdulah dari Kementrian Pariwisata ikut langsung membentuk, dalam Pemilihan pengurus Pak Dar Wis juga gagasan-gagasannya bersama timnya. Diantaranya kuliner ibu-ibu PKK yang mau menentukan tempatnya untuk Warung Kuliner dengan aksesoris yang menarik wisatawan dan penyiapan tempat singgah serta produk yang ditawarkan untuk model pengembangan Desa Wisata Halal.

\section{Halal Tourism}

Wisata halal muncul dari kebutuhan wisatawan muslim sesuai ajaran Islam yakni sesuai dengan AlQuran dan Hadits. Sehingga, Konsep wisata halal merupakan aktualisasi dari konsep ke-Islaman yakni nilai halal dan haram menjadi tolak ukur utamanya.Hal ini berarti seluruh aspek kegiatan wisata tidak terlepas dari sertifikasi halal yang harus menjadi acuan bagi setiap pelaku pariwisata (Chookaew et al. 2015).Hingga kini, belum ada prinsip-prinsip atau syarat utama wisata halal yang disepakati dan tidak banyak literatur atau praktisi yang mendiskusikan dan memaparkan hal tersebut (El-Gohary, 2016).Literatur yang mengangkat hal tersebut dapat dilihat pada Henderson (2010); Sahida et al. (2011); Saad et al (2014). Berikut rangkuman prinsip-prinsip dan atau syarat utama wisata halal dari sumber tersebut: Makanan halal, Tidak ada minuman keras (mengandung alkohol), Tidak menyajikan produk dari babi, Tidak ada diskotik, Staf pria untuk tamu pria, dan staf wanita untuk tamu wanita, Hiburan yang sesuai, Fasilitas ruang ibadah (Masjid atau Mushalla) yang terpisah gender, Pakaian islami untuk seragam staf, Tersedianya Al-Quran dan peralatan ibadah (shalat) di kamar, Petunjuk kiblat, Seni yang tidak menggambarkan bentuk manusia, Toilet diposisikan tidak menghadap kiblat, Keuangan syariah, Hotel atau perusahaan pariwisata lainnya harus mengikuti prinsip-prinsip zakat. 
Namun secara umum, daerah wisata harus mengikuti prinsip-prinsip yang berorientasi pada pengunjung, dimana lokasinyanya membutuhkan layanan jasa untuk menjawab tiga kebutuhan wisatawan yakni:

1. Something to see yaitu sesuatu yang dilihat, diamati, disaksikan atau ditonton bersifat unik dan atraktif.

2. Something to do: sesuatu yang ingin dilakukan berupa kegiatan yang menghibur dan menyenangkan, dan

3. Something to buy: sesuatu yang ingin dibeli sebagai cendera mata (soevenir) berupa produk yang khas daerah serta mudah di kemas.

Berdasarkan beberapa pengertian diatas, maka dapat disimpulkan bahwa destinasi pariwisata adalah suatu wilayah yang mempunyai keunikan dan keunggulan yang mampu membuat wisatawan berkunjung ke tempat tersebut untuk beberapa waktu dan memiliki fasilitas-fasilitas yang mendukung kegiatan pariwisata. Destinasi wisata di Indonesia tersebar di berbagai wilayah Indonesia, disebabkan Indonesia memiliki keunggulan dan keunikan serta fasilitas yang memadai untuk melaksanakan kegiatan pariwisata. (Zaky MLubis, 2018)

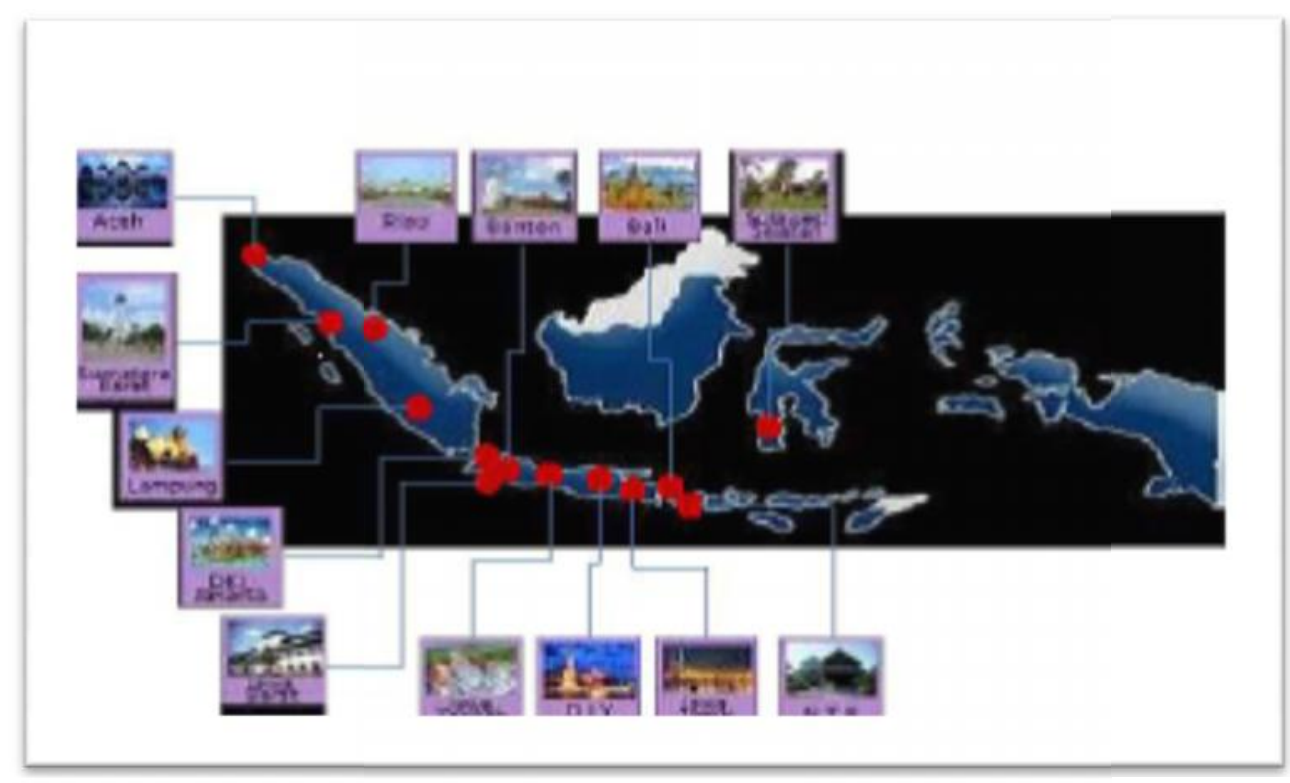

Gambar 2. Sebaran Destinasi Wisata Syariah di Indonesia

Sumber: Kemenparekraf, 2013, Indonesia as Moslem Friendly Destination

Gambar diatas memperlihatkan destinasi wisata syariah di Indonesia yang tersebar di berbagai daerah.Hal tersebut menunjukkan Indonesia memiliki potensi besar dalam pengembangan wisata syariah di dunia.Salah satu daerah tujuan utama adalah Sumatera Barat.Daerah yang dalam anugerah KPHN 2016 menjadi daerah tujuan wisata halal terbaik di Indonesia. Keadaaan alam, budaya serta tingkat religiusitas warga Sumatera Barat yang tinggi membuat potensi Sumatera Barat untuk menjadi destinasi wisata utama tingkat dunia dapat direalisaikan dalam tahun-tahun ke depan. Dan hal yang sama juga dapat ditemui di daerah Selatan Yogyakarta, dimana potensi pantaiPantai selatan identik dengan deburan ombaknya yang besar, sunset di ujung tenggara, dan indahnya pohon-pohon cemara yang berjajar. Salah satu pantainya bernama Kuwaru. Ini adalah sebuah pantai yang sangat potensial dimanfaatkan untuk wisata. Dan kondisi inilah yang dimanfaatkan oleh PPPA Raudhatul Jannah, dimana mereka menawarkan pendidikan bagi para wisatawan khususnya untuk tahfis al-Qur'an, sembari menikmati suasana alam tepi pantai yang tidak jauh dari lokasi pondok berada.

Apabila kita mengacu pada besarnya populasi muslim yang besar baik di Indonesia umumnya dan Yogyakarta khususnya, potensi ini sangat layak untuk dikembangkan dengan konsep-konsep yang menarik.Diperkirakan populasi muslim antara tahun 2015 hingga 2060 meningkat sebesar 70 persen, sedangkan populasi dunia meningkat sebesar 32 persen atau jumlah total populasi dunia pada tahun 
2060 sebanyak 9.6 miliar orang. Hal ini juga menandakan bahwa wisatawan muslim akan terus meningkat. Pada tahun 2020, wisatawan muslim diperkirakan meningkat sebesar 30 persen dan meningkatkan nilai pengeluaran hingga 200 miliar USD (Master Card dan Crescent Rating, 2016).

Adanya peningkatan wisatawan muslim merupakan peluang bagi sektor pariwisata untuk mengembangkan wisata halal. Sehingga beberapa negara mulai mengambil peluang tersebut dengan mengembangkan wisata halal, baik negara dengan mayoritas muslim maupun non-muslim seperti Jepang, Korea Selatan, Australia, dan Thailand. Diharapkan tempat-tempat wisata, hotel, restoran, maskapai penerbangan, agen perjalanan serta semua yang terlibat dalam pariwasata dapat terlibat di wisata halal.Agen perjalanan memiliki peluang wisata halal dalam berbagai bidang (Battour dan Ismail, 2016).

Jumlah restoran halal dan hotel syariah masih terbatas, baik di negara dengan mayoritas muslim maupun non-muslim. Keterbatasan tersebut juga dipengaruhi oleh kurangnya pemahaman terkait halal (El-Gohury, 2016).Oleh karena itu, pendidikan dan program pelatihan terkait halal diperlukan.Sehingga ini dapat menjadi peluang bagi universitas dan pusat pelatihan atau riset untuk menawarkan program tersebut.Selain itu, diperlukan standarisari dalam wisata halal yakni berupa sertifikasi halal di restoran, hotel, dan lainnya.

Tantangan dalam mengembangkan wisata halal salah satunya terkait dengan pemasaran, karena pemasaran wisata halal bukan suatu yang mudah. Hal inidikarenakan perbedaan antara tuntutan wisatawan non-muslim dan wisatawan muslim. Wisatawan non-muslim dapat memutuskan untuk tidak melakukan perjalanan ke objek wisata tanpa adanya atribut tertentu (Battour et al. 2011; Battour dan Ismail, 2016).Sehingga salah satu tantangan wisata halal adalah bagaimana melayani wisatawan non-muslim dan memenuhi kebutuhan mereka tanpa berbenturan dengan konsep wisata halal.Misalnya, beberapa hotel menyatakan bahwa mereka adalah hotel syariah di dalam promosinya dan ini mungkin tidak menarik bagi wisatawan non-muslim. Oleh karena itu, wisata halal dapat menjadi kendala dalam sektor industri pariwisata. Namun juga dapat menjadi peluang bisnis untuk menggunakan kreativitas dan fleksibilitas dalam melayani berbagai kebutuhan wisatawan muslim dan non-muslim. Hal ini juga dapat menjadi kajian atau riset untuk memecahkan masalah tersebut.

\section{Pengembangan Wisata Halal Pondok Pesantren Raudhatul Jannah dalam Rangka Pemberdayaan Umat}

Sebagai lembaga yang bergerak dalam pendidikan Islam, Pondok Pesantren Raudhatul Jannah mencoba menawarkan metode dahwah yang dibarengi dengan konsep wisata halal yang aktifitasnya mengikutsertakan masyarakat setempat dengan konsep pemberdayaan umat atau masyarakat. Pondok pesantren membuat program Wisata Halal dalam meningkatkan ekonomi warga.Program pemberdayaan umat tujuannya meningkatkan produktivitas masyarakat setempat.Seperti makanan tradisional yang diolah menjadi sesuatu yang unik dan menjadi ciri khas.Bantul sendiri adalah pusat penghasil gula kelapa tapi pemanjat pohon kelapa masih tradisional sehingga produktivitas sangat rendah.Dengan program-program layanan pariwisata yang dibuat oleh masyarakat pada wisatawan sekitar pesisir pantai selatan.

Pariwisata halal adalah salah satu konsep yang muncul terkait dengan halal dan telah didefinisikan dalam berbagai cara oleh banyak ahli. Diantaranya Battour dan Ismail (2016) wisata halal adalah kegiatan dalam pariwisata yang 'diizinkan atau dibolehkan' menurut ajaran Islam. Dasar-dasar pariwisata halal termasuk komponen-komponen seperti: makanan halal, transportasi halal, hotel halal, logistik halal, keuangan islami, paket perjalanan islami, dan SPA halal.

Pada prinsipnya, pengembangan wisata halal yang dikemas oleh Pondok Pesantren Penghafal Al Qur'an (PPPA) Raudhatul Jannah adalah wisata syariah yang memerlukan pengenalan pasar pariwisata syariah daerah sekitar pondok pesantren Raudhatul Jannah. Selain itu, keberagaman destinasi wisata yang ditawarkan mendukung pariwisata syariah walaupun destinasi yang difokuskan disini masih terfokus pada wisata religi seperti program utama dari Raudhatul Jannah itu sendiri. Berikut adalah kegiatan yang dilakukan oleh Pesantren Penghafal Al Qur'an (PPPA) Raudhatul Jannah dalam rangka pengembangan wisata halal dengan konsep pemberdayaan umat. 
Program pelayanan wisata dengan mengikuti program Pondok pesantren bisa menghafal al-qur'an

PPPA Raudhatul Jannah adalah lembaga pendidikan Islam di bidang Tahfizhul Qur'an dan Wirausaha yang mengedepankan nilai-nilai Qur'ani, akhlakul karimah, dan keteladanan, sehingga program-program pesantren diarahkan untuk mewujudkan pembinaan karakter berakhlak mulia, pribadi mandiri, dan pribadi yang bermanfaat. Pembiasaan di PPPA Raudhatul Jannah merupakan pembentukan dan perwujudan karakter santri melalui rutinitas kegiatan sehari-hari, berupa kegiatan kepesantrenan dan wirausaha. Pola pendidikan di PPPA Raudhatul Jannah melatih anak/santri \& seluruh civitas akademika untuk mampu hidup hemat, sabar, sederhana, bersahaja, mandiri, pekerja keras, disiplin, bermartabat, dan berkarakter. Lingkungan PPPA Raudhatul Jannah adalah lingkungan sosial berjamaah, di mana perbedaan (Inklusif) harus menjadi rahmat dan melatih kebersamaan di antara semua warga pesantren dan masyarakat sekitar.Program ini dirancang khusus untuk mencetak dan melahirkan para penghafal Al-Qur'an yang benar benar menguasai Al-Qur'an secara lafadz dan ma'na.Harapan kami adalah setelahnya program ini para santri mampu menguasai Al Qur'an $30 \mathrm{Juz}$ serta memahami isi kandungannya.

Program dakwah PPPA Raudhatul Jannah yaitu membuat program singgah bagi para wisatawan yang berkunjung, dipersilahkan untuk belajar al-Qur'an, mengetahui cara membaca dan tajwid serta menghafalnya. Ternyata para wisatawan sangat suka dengan sajian yang diberikan pada mereka, dengan lebih sering mengadakan kunjungan ulang setelah jalan-jalan di sekitar pantai selatan berkunjung untuk lebih mendalam mempelajari tentang al-Qur'an.

Pelatihan pengembangan wisata halal dan menjadikan pondok pesantren sebagai jantung perekonomian

\section{a. Pelatihan membuat kaligrafi}

Program Pemberdayaan pesantren dan masyarakat dimasa pandemi ini dengan KGM

(Keluarga Gama Mandiri) kelompok penggiat usaha alumni Universitas Gajah Mada berupa pembuatan kerajinan kaligrafi yang bisa dilakukan oleh santri, ustadz ataupun masyarakat yang berminat, sistimnya santri juga masyarakat mengerj kaligrafinya Al Fatihah, ayat kursi dan lain lain kemudian Finishing menjadi lampu dan lain-lain akan

\section{b. Pelatihan membuat kerajinan besek}

Pelatihan membuat kerajinan besek, dengan melibatkan masyarakat sekitar. Dimana saat Idul Adha lalu, besek sudah digunakan untuk membagi daging korban. Juga menjalin kerjasama dengan banyak insan Perguruan Tinggi (PT) untuk bisa mengembangkan jiwa wirausaha seperti dengan DR. Kintoko Universitas Ahmad Dahlan (UAD) maupun Prof. Dr. Waryono Abdul Ghafur, UIN Sunan Kalijaga.Juga pengembangan perkebunan dan pertanian dengan menggandeng insan kampus IPB Dr. Sugeng Budi Harsono, maupun Kampus INTAN Yogyakarta Prof. Indro.Di sini potensi pertanian dan perkebunan bisa dikembangkan.Jadi Pondok ini bukan hanya konsen di internal tetapi juga lingkungan.

c. Membuat alat pemanjat pohon kelapa

Contoh lain yang telah dibuat oleh Pesantren Penghafal Al Qur'an (PPPA) Raudhatul Jannah adalah membuat alat pemanjat pohon kelapa yang aman bagi masyarakat.

\section{d. Beternak lele}

Untuk tambahan ilmu dan refresing, santri juga belajar ternak lele juga bercocok tanam bersama dan Ternak Kambing guru pada Prof. Dr. Drh. Hartiningsih,M.P. dari Fakultas Kedokteran Hewan UGM

\section{e. Perawatan kambing}

Santri juga belajar berternak kambing dan bekerja sama dengan mitra Idul Qurban tahun termasuk juga ikut juga menjual kambing kurban tersebut. Pada awal ide ini direalisasikan, PPPA Raudhatul Jannah memiliki lebih kurang 13 ekor kambing. Program ini diharapkan dapat memberikan manfaat khususnya bagi santri yang mencintai hewan ternak seperti 
kambing. Dan harapannya juga bisa jadi stimulan bagi santri untuk berprestasi, dan diberikan hadiah berupa kambing.

Untuk kambing ternak sendiri, PPPA Raudhatul Jannah bekerja sama dengan Mitra Raudhatul Jannah sudah mulai melakukan ternak kambing dari pertengahan tahun 2019 satau indukan dan sudah beranak 2 kali dengan anakan pertama jantan 2 ekor. Bahkan untuk anakan yang pertama, pengelola sudah bisa menjual hasilnya seharga Rp.5.200.000,-. Untuk perhitungan indukan 20 ekor biaya 1 tahun 12 juta dengan beranak 40, pihak pengelola akan menjual jual rata-rataharga Rp.1500,000,-. anaknya terjual 60 juta induk masih utuh harga indukan hamil 1,600,000 per ekor. Apabila sistem beli indukan yang sudah hamil, anaknya sampai 50-60 ekor pertahun.

Semua proses yang dilakukan selalu bekerja sama dengan pihak-pihak yang dianggap mumpuni dibidangnya. Seperti proses perawatan kambing ini juga bekerja sama dengan Departemen Ilmu Bedah dan Rafiologi FKH UGM. Santri diajarkan bagaimana merawat kesehatan kambing, kemudian bagaimana menjaga kebersihan kandang dan lingkungan sekitar akandang serta bagaimana menjaga kepadatan ternak dalam setiap kandang yang ada.

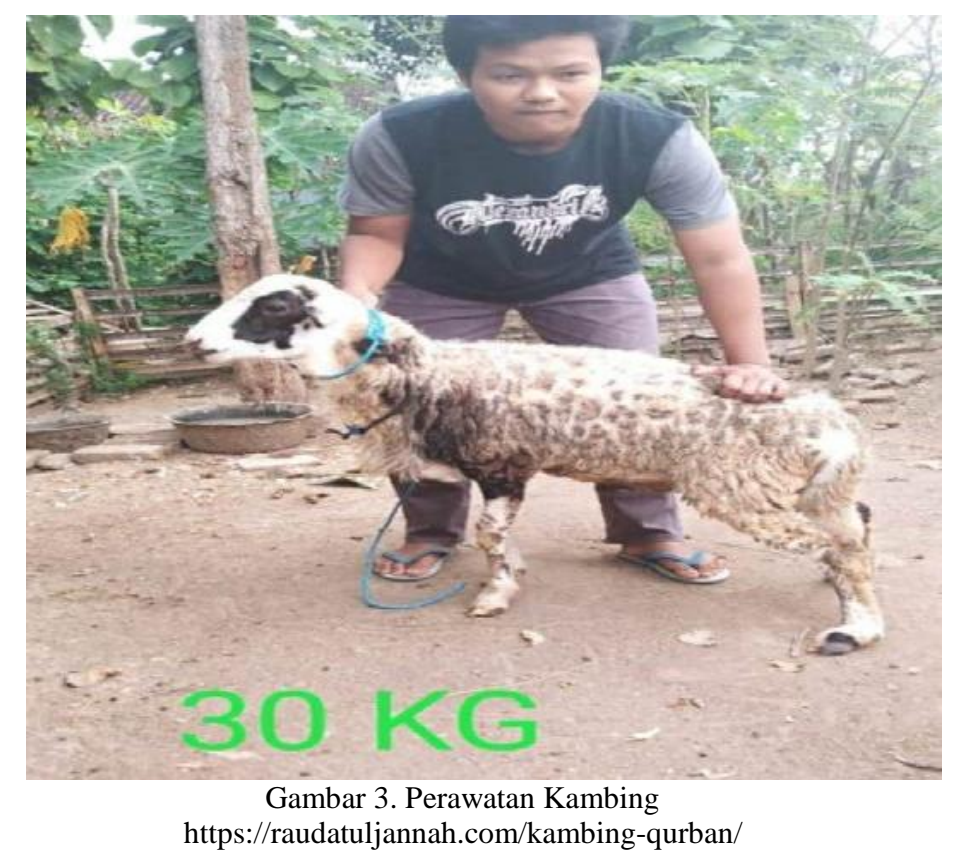

Penempatan ternak berdasar kondisi ternak yang ada, mulai dari kambing yang sedang hamil, menyusui, sapih, betina tidak hamil dan pejantan. Santri juga diajarkan bagaiman cara pemberian pakan ternak, bahkan juga diberitahu bagaimana mengkondisikan kandang yang sehat dan tepat untuk pencahayaan matahari pagi ataupun sore hari.

Hasil dari peternakan kambing ini juga sudah dirasakan oleh PPPA Raudhatul Jannah dengan masyarakat sekitar dengan keikutsertakan pondok dalam menyediakan hewan kurban pada Hari Raya Idul Adha $1441 \mathrm{H}$.

\section{f. Penanaman Jeruk}

Dengan berkebun juruk ini tentu saja pihak pengelola berharap ada manfaat finansial yang akan didapatkan. Pemilihan jeruk karena akan mendapat manfaat dari ketahanan jeruk terhadap pengangkutan (karena kulitnya yang tebal) dan kemampuannya untuk disimpan dalam waktu lama dalam kondisi tertentu. Dan yang paling penting dapat memberi petani jeruk lebih banyak waktu untuk menegosiasikan harga yang lebih baik untuk produk mereka dan untuk mendapatkan keuntungan dari fluktuasi harga jeruk sepanjang tahun 


\section{g. Berkebun Pisang}

Dalam perhitungan pihak pengelola, penanaman pisang dalam jumlah banyak akan sangat menguntungkan dan perawatannya juga tidak terlalu rumit. Lahan banyak tersedia dengan bekerja sama dengan masyarakat sekitar. Perkiraan dengan menanam 50 pohon, diperkirakan akan satu pohon punya akan memiliki anak 4 yang akan tumbuh. Kebutuahn masyarakat akan pisang cukup baik, dan dengan harapan itu, pemberdayaan umat yang dimaksudkan oleh pihak PPPA Raudhatul Jannah bisa tercapai optimal dan memberikan manfaat finansial yang cukup menguntungkan.

\section{Simpulan}

Adanya peningkatan wisatawan muslim dari tahun ke tahun merupakan peluang dan tantangan bagi sektor pariwisata untuk mengembangkan wisata halal. Banyak negara-negara (baik mayoritas muslim maupun non-muslim) berupaya mengembangkan wisata halal. Namun, dilihat dari konsep dan prinsip wisata halal yang ada, negara-negara tersebut umumnya hanya mencoba menciptakan suasana yang ramah muslim. Pengembangan wisata halal perlu untuk dilakukan, yaitu dengan membuat program paket wisata dengan mengikuti program Pondok pesantren bisa menghafal al-qur' an dan mengadakan pelatihan pengembangan wisata halal dan menjadikan pondok pesantren sebagai jantung perekonomian.

Selain itu, PPPA Raudhatul Jannah membuat program Halal Tourism dalam Peningkatan Ekonomi Umat dengan memberikan paket pariwisata dengan menyediakan tempat singgah dan menyediakan oleh-oleh berupa pembelajaran al-Qur'an untuk menjadi tahfidz serta mempelajari al-Qur'an. Peningkatan kunjungan wisatawan memberikan peluang dan tantangan pada pariwisata untuk mengembangkan wisata halal.Pelatihan pengembangan wisata halal menjadikan pondok pesantren sebagai jantung perekonomian dengan membuat Anak Panah beserta busurnya bisa untuk berwisata.

Selain itu, PPPA Raudhatul Jannah juga melakukan pengembangan usaha yang melibatkan masyarakat dan santri. Adapun usaha yang dipilih adalah beternak lele, kambing, menanam jeruk dan pisang. Pemberdayaan yang dilakukan bekerjasama dengan pihak-pihak yang telah berpengalaman dengan melibatkan masyarakat sekitar dan juga santri yang ada.

\section{Referensi}

Battour, M, dan Ismail, MN. 2016. Halal Tourism: Concepts, Practises, Challenges and Future. Tourism Management Perspective. 19: 150-154

Battour, M., Ismail, MN, dan Battor, M. 2010.Toward a Halal Tourism Market.Tourism Analysis. 15(4): 461-470

Chookaew, S., Chanin, O., Charatarawat, J., Sriprasert, P, dan Nimpaya, S. 2015.Increasing Halal Tourism Potential at Andaman Gulf in Thailand for Muslim Country.Journal of Economics, Business and Management. 3(7): 739-741

Eka Dewi Satriana, Hayyun Durrotul Faridah, Wisata Halal: Perkembangan, Peluang, Dan Tantangan. Journal of Halal Product and Research (JHPR) Vol. 01 No.02, Mei-November 2018

El-Gohary, H. 2016. Halal Tourism, is it Really Halal?.Tourism Management Perspective. 19: 124130

El-Gohary, H. 2016. Halal Tourism, is it Really Halal?.Tourism Management Perspective. 19: 124130 
Hamdan, H., Issa, ZM., Abu, N, dan Jusoff, K. 2013. Purchasing Decisions among Muslim Consumers of Processed Halal Food Products.Journal of Food Products Marketing. 19(1): 54-61.

Henderson, JC. 2010. Sharia-compliant hotels. Tourism and Hospitality Research. 10(3): 246-254

M. Zaky Mubarak Lubis, 2018. Prospek Destinasi Wisata Halal Berbasis Ovop (One Village One Product). Maqdis : Jurnal Kajian Ekonomi Islam - Volume 3, Nomor 1, Januari - Juni 2018

Master Card and Crescent Rating. 2016. Global Muslim Travel Index 2016. Diakses Agustur 2020 pada https://www.crescentrating.com/reports/mastercard-crescentrating-global-muslimtravelindex-gmti-2016.html.

Mohsin, A., Ramli, N, dan Alkhulayfi, BA. 2016. Halal Tourism: Emerging Opportunities. Tourism Management Perspective. 19: 137-143.

Rahman, RA., Rezei, G., Mohamed, Z., Shamsudin, MN, dan Sharifuddin, J. 2013. Malaysia as Global Halal hub: OIC Food Manufacturers' Perspective. Journal of International Food and Agribusiness Marketing. 25: 154-166

Saad, H., Ali, B, dan Abdel-Ati, A. 2014. Sharia-Compliant Hotels in Egypt: Concept and Challenges. Advances in Hospitality and Tourism Research. 2(1): 1-13

Sahida, W., Rahman, SA., Awang, K., dan Man YC. 2011. The Implementation of Shari'ah Compliance Concept Hotel: De Palma Hotel Ampang, Malaysia. 2nd International Conferences Humanities. Singapore: Historical and Social Sciences.

Samori, Z., Md Salleh, NZ, dan Khalid, MM. 2016. Current Trends on Halal Tourism: Cases on Selected Asian Countries. Tourism Management Perspective. 19: 131-136. 